DOI: 10.2478/RAE-2019-0013 Review of Artistic Education no. 172019 118-125

\title{
13. THE DEVELOPMENT OF DM. KABALEVSKII IDEAS IN CONTEMPORARY MUSICAL PEDAGOGY
}

\begin{abstract}
Musical pedagogy has a long way of training and development. Over the decades, we can follow schools, systems and personalities through which this area is grounded. Based on various factors, such as the geographical location, the purpose of the system or school pursued, the possibilities of interpretation, the contemporary musical pedagogy enumerates well-known personalities, on whose researches this field is based. Dm. Kabalevsky's name and his successors notably record in the musical-educational system of the Republic of Moldova.
\end{abstract}

Key words: musical pedagogy, musical educational systems, well-known personalities, Dm. Kabalevsky

\section{Introduction}

In the world of musical art Dmitri Kabalevsky is considered a unique personality. The name of the researcher, composer, musical critic, composer of the students music education concept, Dmitri Kabalevsky (1904-1987), is an illustrious person who have consecrated life-long activity to the education of children and younger generations. Going through the tabs of history, you can see Dmitri Kabalevsky's multilateral and all-embracing activity. Opportunity for early childhood education, taking the ideas of the philosophers R. Descartes, F. Bacon, I. A. Comenius, etc., and also the great musicians J.F. Ramo, I.S. Bach and others, being sure that the higher is the spiritual baggage of the child, the easier it will integrate into life.

Being the disciple and successor of B. Asafiev, A. Goldenveizer, G. Katuar, $\mathrm{N}$. Meascovsky, he took part in the fundamental changes in the musical education processes. Life and activity testify to us that throughout his live, Dm. Kabalevsky permanently became self-confident in his profession as a teacher of musical education. He rises to the peaks of his pedagogical mastery as a musician-performer, a musical critic, a scholar in the field of musical art, constantly developing new ideas and directions of research, etc. The musical art and children were the basis of the conceived conception. Dm. Kabalevsky extended the ideas of the great thinkers, like J. J. Ru kosso, J. Pestalozzi, L. Tolstoi, B. Asafiev, through traditions related to the formation of the multilateral personality. Together with such famous names as O. Apraxina, N. Briusova, N. Vetlughina, N. Grodzenskaia, V. Şaţkaia, S. Şaţky, L. Predtecenskaia and others, Dm. Kabalevsky worked on the musical-educational system for teacher

\footnotetext{
${ }^{125}$ Lecturer, Doctoral Candidate, „Alecu Russo” State University from Bălţi, Republic of Moldavia, email: caligamarina@inbox.ru
} 
education and musical education of students. Through this system, scholars have researched and experienced the traditions of national and international musical pedagogy that have been grounded in the achievements of world music culture.

\section{Discussions}

Dmitri Kabalevsky is one of those who has made a huge contribution to musical pedagogy. The ways approached by the researcher integrate the elements of different musical-educational systems. In 1963 Dm. Kabalevsky attends an international conference on international music education - ISME (International Society for Music Education) held in Japan. The theme the scholar approaches in this important forum is „The composer, the music, the children”. Thus, we observe the formulation of the integral conception of the educational trivium of the activity of the composer, teacher-interpreter and educator. „Composing music for children it is few to be a composer. The composer makes sure the composite music is good and accessible to the children. The teacher will ensure that the lesson is approached according to pedagogical laws, and the educator, through art, will help children to know the world around them, nature, the world" [3]. Dmitri Kabalevsky's pedagogical secret is that the music teacher must first know at the high level the domain that he communicates with children. A whole pedagogical process based on different branches in the activity for many years as a composer, interpreter, promoter of musical art, poet, scholar, teacher-experimenter and others, he did all this in the general school. By supporting his work on the ideas and concepts of his predecessors in the musical-educational field, he proposes a new conception in the teaching of Music.

This conception was the last „Pedagogical Symphony” of the researcher, the aim of which is to nawadays: ,the formation of musical culture as a component part of spiritual culture" [5, p. 6]. The main idea of Dmitri Kabalevsky was formed by integrative ideas: the formation of pupils' musical culture as a component part of their spiritual culture; the connection of music with life; Supporting the „Music” program on musical art laws; integration of musical art with other arts (literature, plastic art, theater, cinema, etc.); the complete „Music" curriculum through thematic (thematic links from one class to another); the development of the musical form, the musical image, the musical dramaturgy, the theme of the theme, etc.

Dm. Kabalevsky has opened a path for students to the art of music as a "source of spiritual communication" through the following directions:

$>$ The principle of connection of music to life: „Music and life - is the general theme, which must integrate all levels of school” [5, p. 14]. „Musical art will have a real development only if its integration with life itself is achieved" [5, p. 20].

$>$ The issue of passion and cointerference in musical art [4, p. 1-6]. Musical perception - is researched as the foundation of the musical activity of students: 
the term ,perception of music" can not be equated with the term „listening to music". „It has to be educated in the students to listen to music and really hear it" [5, p. 22].

$>$ Musical knowledge and music: perception of emotional music; perceiving the characters of the music; who are the authors of music, etc. „Musical grammar - is the musical culture" [5, p. 19].

$>$ The principle of the theme: the thematic principle of the Music program solved a pedagogical problem - the problem of completeness of the lesson in a whole with the elements of the lesson through the musical-didactic activities of the pupils (vocal-coral song, musical knowledge, musical-rhythmic movement, description of music, etc.). „The lesson must always be integral, united by its component elements into a main idea: music-musical interpretation" $[5, \mathrm{p} .11$ 12].

Referring to this principle V. School: „All contemporaries of Dmitri Kabalevsky are witnesses to the methodological phenomenon - methodological art research through the dialectical logic method" [3]. The building of the program according to the theme of the theme has contributed to such a new conception as the integral of the lesson, that is, the union of all the elements present in the lesson in the whole, which sucks the lesson of Music.

$>$ The „Three Whale" - a generic and accessible idea of all three-character music, from which the great art of music derives (opera, ballet, symphony, instrumental and choral concerts, religious music, folk music, etc.).

$>$ Various musical-didactic activities at the lesson: 1) the vocal-coral song „Every Class - Choir!”, The protogonist, chooses to study different genres, forms, musical styles, epochs; 2) interpretation of various musical instruments for children, even confidential (temp, stamp, rhythm, height, etc.); 3) the musical-rhythmic movement and other AMD at the lesson [5, p. 25].

$>$ Integration of different genres of art into the music lesson: music and literature, music and fine arts, music and theatrical art, choreography, etc. [5].

Through the conception and ideas developed for musical education, through the pedagogical experience, the scholar describes different working methods, eg: creative friendship with the class of students; creating emotional atmosphere through the perception of musical art; the expressive interpretation of music; the connection of musical art with different arts (aerobics, plastic art, cinema, choreography, theater, etc.). One of the main focus of musical education was to translate the emphasis from learning objectives into educational ones. This position is certified by the motto of „Music": „By music education we do not educate musicians but personalities" V. Suhomlinsky. In this respect, Dm. Kabalevsky through this epigraph penturu program opens the way for students to musical art as a ,source of spiritual communication”

Applying Dmitri Kabalevsky's conception in the educational system is current in our times. Its originality is based on one of the principles: the connection of music with life, widening the cultural space of the pupil through 
educational processes. „Music and life - are two general themes of the Music program, which in one case can not be dispersed. This theme has to be integrated with all subjects and contents beginning with the first stage, finishing with the final one" [4, p. 14]. By deepening our research on this principle, we highlight another very important issue, researched, experienced and proposed by the great scholar. This is the concept of "Three Whale”. Under this interesting name, the teacher investigates the meaning of genres „song”, „march”, „dance”, which in turn have opened doors to the great art of music and other arts (opera, ballet, symphony, instrumental concerts, vocal-choral music starting with a swing song, religious song, reaching the great treasures of vocalchoral art, etc.) [2]. We see the idea of the „Three Whale" concepts by musicologist L. Barenboim: „Everything that is integrated into the Three Whale is profoundly thoughtful, but the most important thing is that it draws its roots in the qualities of the most sacred personality, with the retrospective of time does not change from its values" [1].

Deepening into Dmitri Kabalevsky's conception it is noticed another aspect of this concept: the competence to perceive musical art as a living art, which contributes to the treatment of the notion of musical grammar. This competence opens the ways in perceiving music by: knowing the genre of music, the historical period of the composer who composed the creation, the integral perception of the character of the interpreted music, etc. Music perception is treated as a foundation of student activity, making a difference between the terms ,perceiving music” and „listening to music”. Developing the concept of B. Asafiev, the „pursuit of music”, Dm. Kabalevsky urges teachers to an aesthetic, knowledge-based, and educational discovery of musical art in the process of working with students.

Thus, we observe this in the general themes of the conception: the intonational nature of the music; the language of music; the style of music; the form of musical creation; musical image; musical dramaturgy; the completeness of different arts at the Music lesson - certifies the multilateral thinking of the scholar, who during the rich experience of working with children in general school has contributed to the acquaintance and acquisition by the students of the laws of musical art. Through the new conception, a way has been opened for music education teachers. Through these new ideas and concepts Dm. Kabalevsky became a fighter diplomat. The way of becoming was not easy at all, as our teachers (who did not understand the concept well) have come to terms with us, even from professional interpreters, composers and other people in the musical-educational field.

But the experimentation of the proposed theories and concepts are based on real concepts. He works as a professor at the Music Faculty on behalf of A. Gherten, where musical education teachers were preparing for a new system, a system developed by Dm. Kabalevsky. His experiment approves him in Number 209 general school in Moscow. The lesson is experimented on the basis of 
methodological meetings and seminars for teachers, lessons were broadcast on television and radio by the most experienced teachers. A great support for the new program was made by the Union of Musicians by enrolling the musical materials for audition at the Melodia Association, the Soviet Composer and Music in the School. The current up to date is the „Music Teacher” magazine, which Dmitri founded. Kabalevsky, this magazine is currently directed by the daughter Maria Kabalevsky.

It is clear from the fact that Moldova during Dm. Kabalevsky's life worked on the scholar's conception, the same public television lessons were practiced. The photos are attached at the end of the article. On one of these pictures is Mrs. Liuba Popovskaia, who, on the occasion of the school years 1979-1989, supported the public lessons at Teleradio Moldova 1 monthly with the pupils from the „Mihai Eminescu” Theoretical High School in Balti. Once again, we attach the pictures with the event on 18-20 October, 2018 ,Developing the ideas of academician Dm. Kabalevsky in Contemporary Artistic Pedagogy”, which took place at Alecu Russo State University in Balti.

This round table was organized by project director Marina Morari, Ph.D., Associate Professor at the Art and Artistic Education Chair, and hired over 250 teachers across the country. At which the theoretical and methodological problems related to the musical education curriculum were discussed, challenges and perspectives. There were many experienced teachers who, since the Soviet era, have worked on Dmitri Kabalevsky's program. The author of this article came up with a greeting message through a song „School Years”, written by Dmitri Kabalevsky. The Coral Arrangement Vitaly Popovici and Marina Caliga. Translation of Russian text Margarita Curtescu, philologist, poet, associate professor at the Faculty of Letters. Also, once we attach the pictures to Dm's daughter. Kabalevsky, choir of Ion Creangă Republican Theoretical High School, led by Marina Caliga [7].

\section{Conclusions}

From the presented ones we come to the idea that the scientist Dmitri Kabalevsky permanently sought to solve the new creative issues in the field of musical education, the problems characteristic of the time and the age in which he lived, problems that force his country to be resolved and contribute to the formation of man through musical education. In this way, this area also arises the pedagogy of the arts. Dmitri Kabalevsky perceives the art of music as an art through which you can communicate: „Only the musical art will give impetus to the sense through music". If we make a retrospective analysis on the development of musical pedagogy of the twentieth century, we are convinced that Dmitri Kabalevsky's artistic and pedagogical conception is an integral conception, is a scientific-methodological system. From one point of view, this concept has integrated the knowledge of musicology, psychology, didactics, 
culturology, sociology, etc. from another, came as a reform in the formation and development of pupils' personalities.

\section{References}

1. Barenboim, L. A. Puti k muziţirovaniu. Izd. 2-e, dopol. Leningrad. 1979

2. Kabalevsky, Dm. Cultivarea cugetului şi sufletului. Chişinău: Lumină. 1987

3. Kabalevsky, Dm. Uciteli muzâchi // Muzâca v școle.1984. № 1. p. 1 - 6.

4. Kabalevsky, Dm. Pro treh chitov i pro mnogoie drugoie. Moscova: Detskaia literatura. 1970. $224 \mathrm{p}$.

5. Programa po muzâche (s pourocnoi metodiceskoi razrabotkoi) dlea obsceobrazovatelinoi școlâ. 1-3 clasâ. Naucnâi rucovoditeli Dm. B. Kabalevsky / E. B. Abdulin. Moscva. Prosvescenie. 1985. 118 p.

6. Școlear, V. Obnovlenie soderjania muzâcalinogo obrazovania s metodologhiceschih poziții. Moscova: Flinta, 1999. 88 p.

7. http://kabalevsky.ru/news/simpozium-Moldova

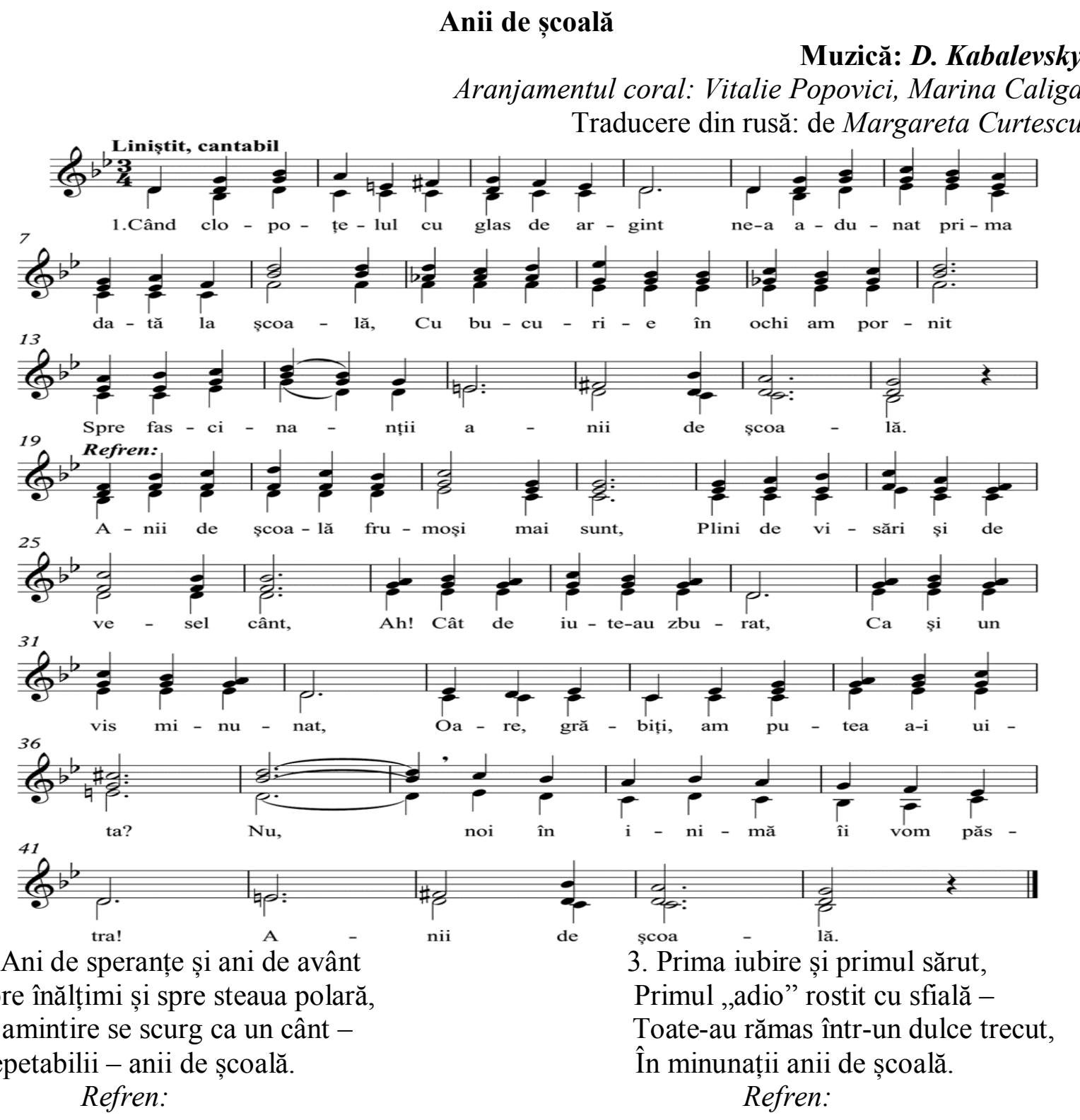




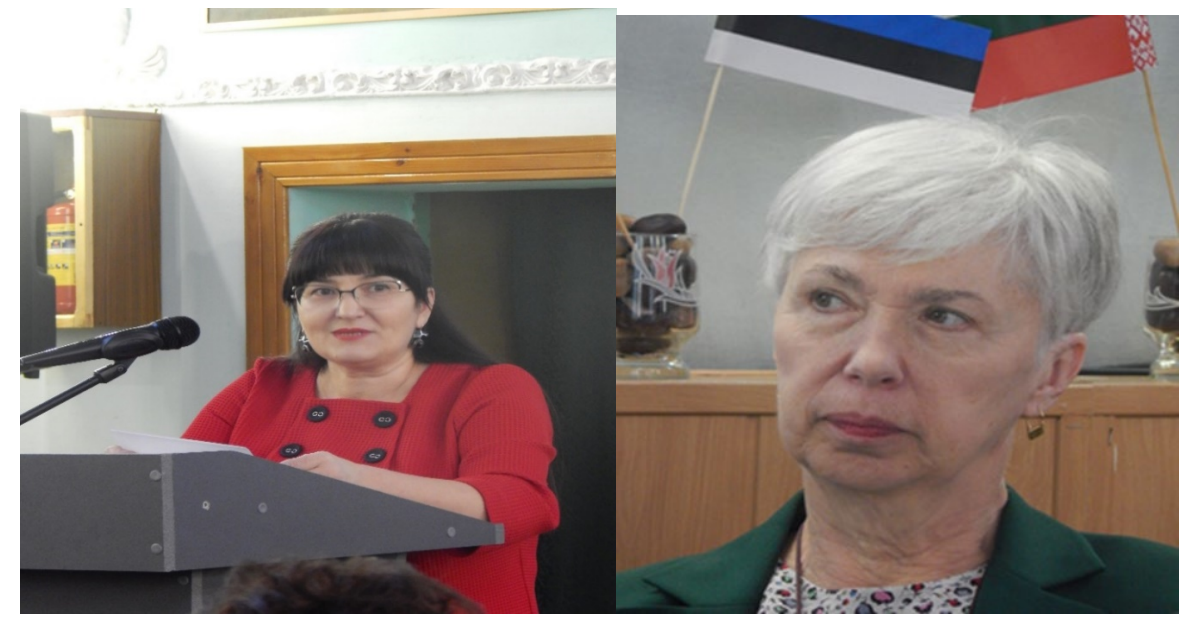

Mis Marina Morari, the Project Director

Mis Maria Kabalevskaia, the Director of the Magazin „Profesorul de muzică” (the Music Teacher)

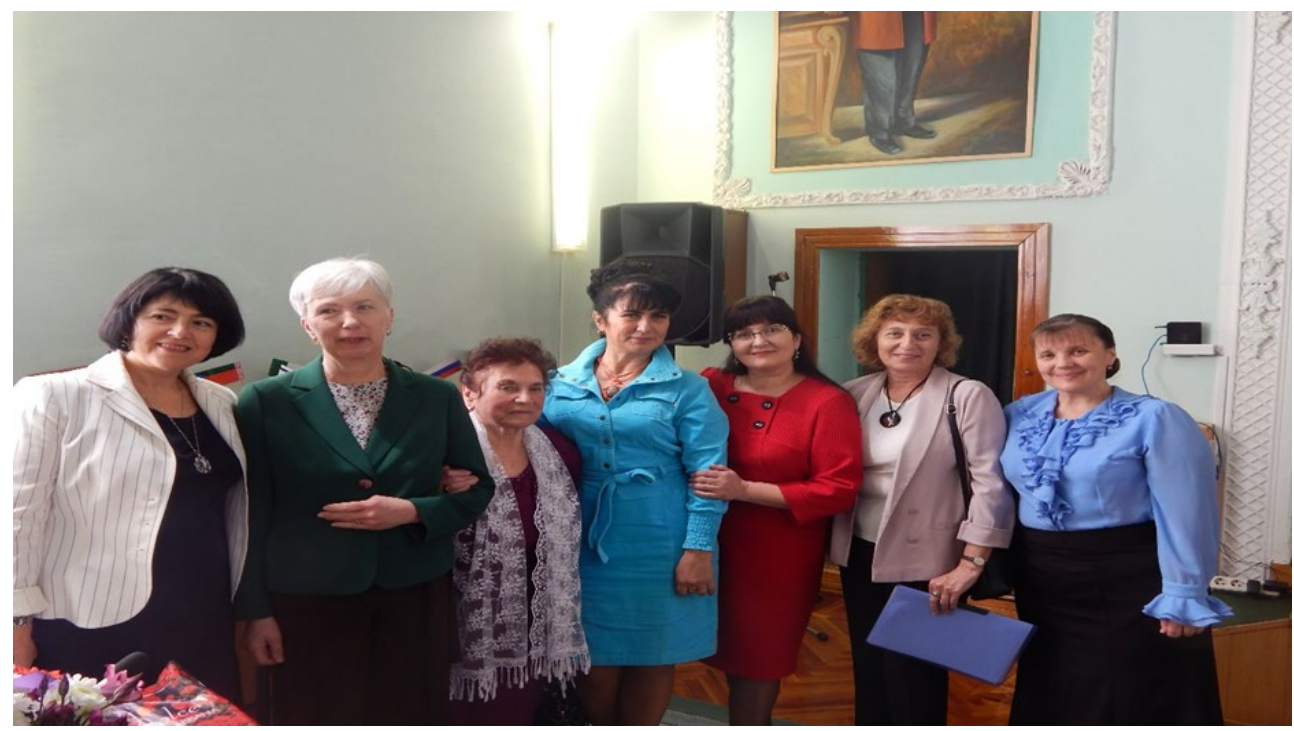

A group of teachers from the Department „Art and Artistic Education”

(the third on the left - Ms Liuba Popovsky, experimenting professor according to Dm. Kabalevsky's curriculum, years of studies 1979-1989)

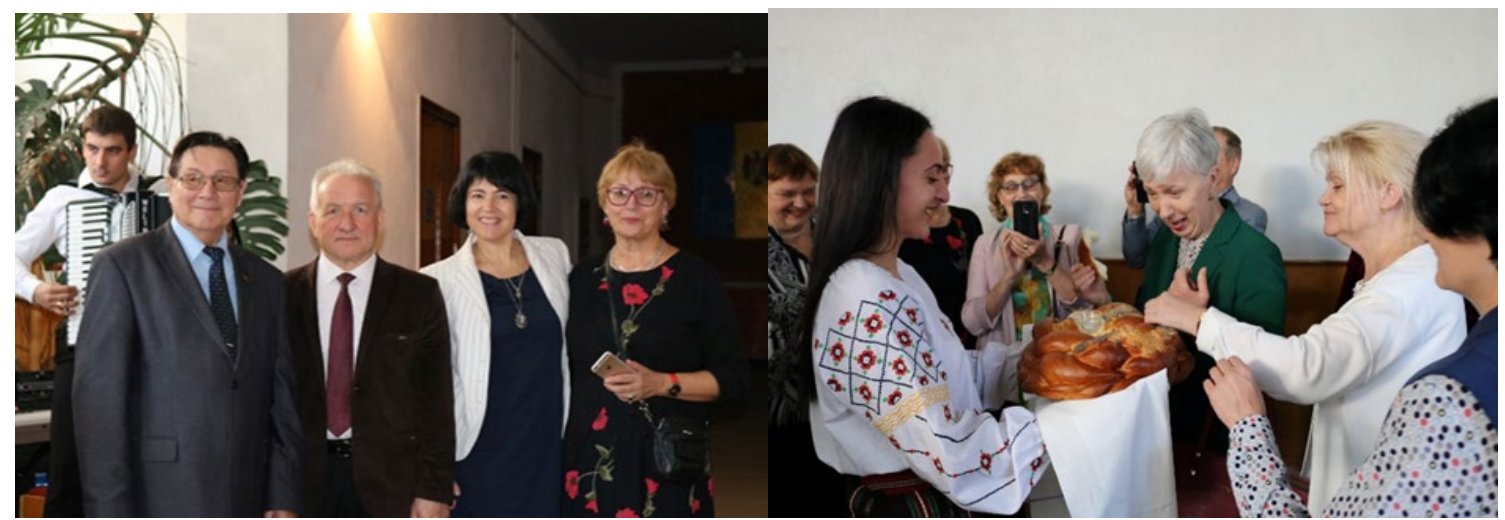

Mr. Iulii Aliev-profesor from Russia; Mr. Ion Gagim and Lilia Granetky profesors and doctors from Republic of Moldova, Tiina Selke- profesor from Estonia. 

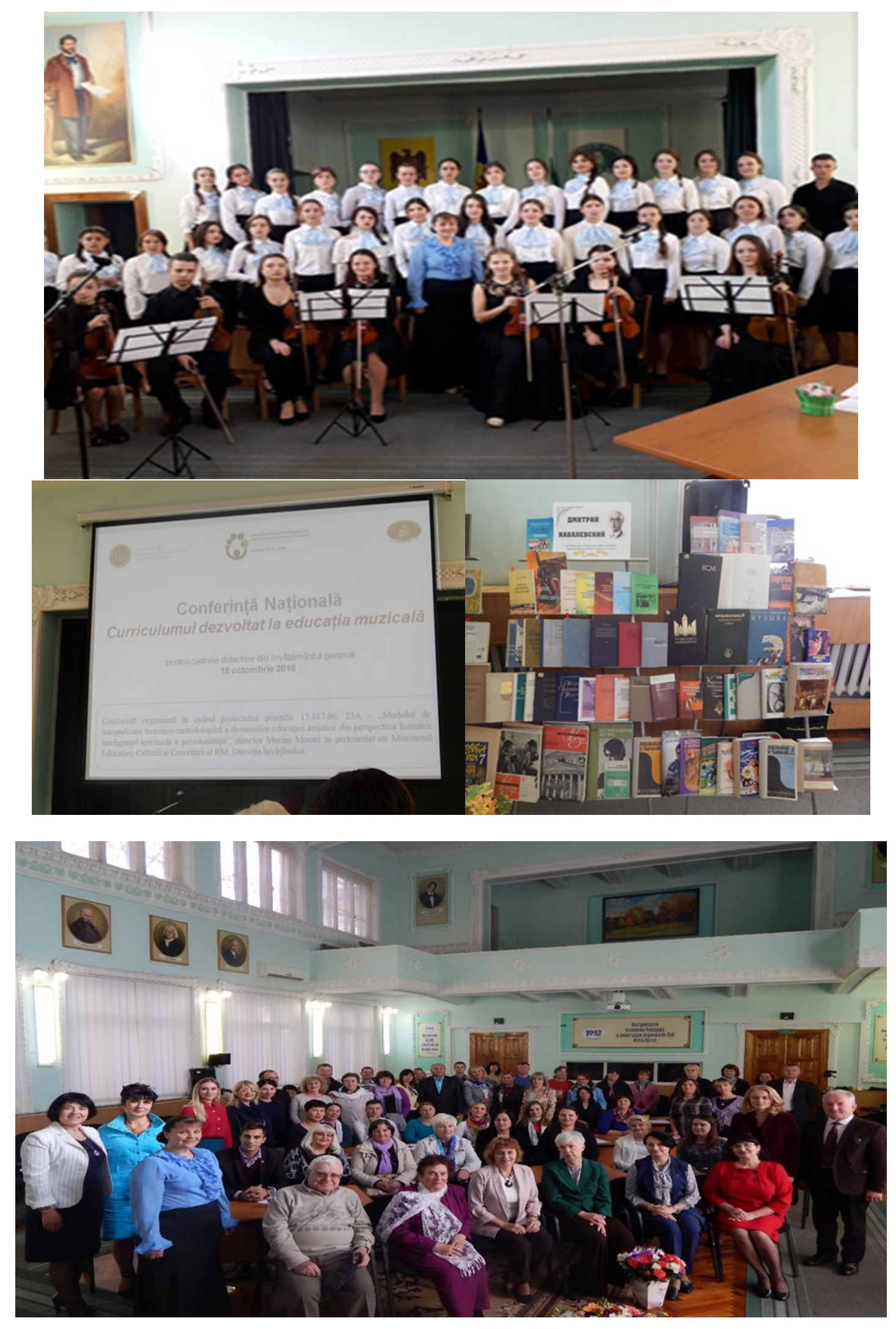